\title{
KADAR MINERAL DALAM DARAH DAN JUMLAH BAKTERI DALAM RUMEN KAMBING YANG DIBERI JERAMI JAGUNG DAN SUPLEMEN UREA GULA AREN BLOK
}

\author{
Charles L. Kaunang dan Endang Pudjihastuti \\ Fakultas Peternakan Universitas Sam Ratulangi Manado \\ e-mail: charleskaunang@unsrat.ac.id
}

\begin{abstract}
ABSTRAK
Penelitian ini bertujuan untuk mengkaji efektivitas penanggulangan kekurangan mineral melalui pemberian urea gula aren blok (UGB) pada kambing dengan melihat perubahan kandungan beberapa mineral dalam darah, juga menghitung jumlah bakteri dalam rumen. Penelitian dilaksanakan selama 3 bulan. Ternak yang digunakan terdiri dari 24 ekor kambing betina lokal, berumur \pm 1 tahun dengan berat badan \pm 18 $\mathrm{kg}$. Kandang yang digunakan adalah kandang individu dengan ukuran $2 \times 2 \times 1 \mathrm{~m}$, yang dilengkapi dengan tempat makan khusus untuk penempatan UGB. Hijauan yang digunakan adalah jerami jagung, Pakan tambahan UGB diberikan secara konstan sebanyak $300 \mathrm{~g} /$ ekor/hari dan air minum diberikan secara ad libitum. Ransum perlakuan yang diberikan diatur sebagai berikut Ro = Jerami jagung ad libitum + o gram UGB dan R1= Jerami jagung ad libitum + 300 g UGB. Variabel yang diamati adalah kadar mineral (Ca, Mg, $\mathrm{P}, \mathrm{Na}, \mathrm{K}$, dan $\mathrm{Cl}$ ) dalam darah dan jumlah bakteri dalam rumen kambing. Data yang diperoleh dianalisis dengan menggunakan t-test. Kesimpulan yang didapat dari penelitian ini adalah bahwa pemberian jerami jagung dan mineral blok (UGB) dapat meningkatkan kadar mineral dalam darah dan meningkatkan jumlah bakteri dalam rumen kambing
\end{abstract}

Kata kunci: kambing, jerami jagung, UGB, mineral, bakteri

\section{MINERAL LEVELS IN THE BLOOD AND THE NUMBER OF BACTERIAL COLONY IN GOAT RUMEN GIVEN WITH CORN STRAW AND UREA PALM SUGAR BLOCK}

\begin{abstract}
This study aims to evaluate the effectiveness of mineral deficiencies treatment by feeding goats with palm sugar block (PSB). Changes of blood mineral content and microbial count in goat rumen were analyzed parameters in this study. This study was done for 3 months. The livestock used consisted of 24 local female goats, aged \pm 1 year old with a body weight of $\pm 18 \mathrm{~kg}$. The enclosure used for this study was an individual encolusre with a special dining area for PSB placement. Forage used was corn straw, additional PSB was given constantly as much as $300 \mathrm{~g} / \mathrm{head} /$ day and drinking water is given ad libitum. The treatment ration given were regulated as follows Ro $=$ Corn ad libitum $+\mathrm{o}$ gram UGB and R $1=$ Ad libitum corn straw +300 g PSB. The variables observed were blood mineral contents $(\mathrm{Ca}, \mathrm{Mg}, \mathrm{P}, \mathrm{Na}, \mathrm{K}$, and $\mathrm{Cl}$ ) and bacterial count in goat rumen. The data obtained were analyzed using t-test. We concluded that the administration of corn straw and PSB could increase blood mineral content and increase the bacterial count inside goat rumen.
\end{abstract}

Keywords: goat, corn straw, PSB, mineral, bacterial

\section{PENDAHULUAN}

Ada beberapa faktor yang dapat menyebabkan penyakit defisiensi mineral, dan hal tersebut berkaitan dengan sistem pemeliharaan. Ternak umumnya dipelihara dengan dilepas di padang penggembalaan dan pakan yang diberikan hanya seadanya. Beberapa penelitian menunjukkan beberapa jenis unsur mineral dalam jerami jagung relatif rendah. Rendahnya kandungan mineral dalam tubuh ternak, menyebabkan terjadinya defisiensi mineral.

Mengingat besarnya kerugian yang diakibatkan apabila ternak mengalami kekurangan mineral, maka perlu adanya usaha-usaha yang dilakukan dalam rangka penanganan maupun pencegahan penyakit defisiensi pada ternak.

Tujuan kegiatan ini adalah untuk mengkaji efektivitas penanggulangan kekurangan mineral melalui pemberian UGB pada ternak kambing, dengan melihat perubahan kandungan beberapa mineral dalam darah. Selain itu penelitian ini juga 
mengukur peningkatan jumlah bakteri dalam rumen akibat pemberian UGB.

Jerami jagung merupakan limbah peranian yang tersedia sepanjang tahun dalam jumlah yang cukup besar. Rendahnya kualitas hijauan seperti jerami jagung dapat dilengkapi dengan pemberian suplemen. Kandungan mineral jerami jagung Ca: $0,03 \mathrm{~g} / \mathrm{kg}$; $\mathrm{P}$ : o,17 g/kg; Mg: 0,03 g/kg; Na: 0,o8 g/kg; K: o.,4 g/kg; Cl: $0,10 \mathrm{~g} / \mathrm{kg}$ (Lab. Fapet Unsrat, 2019). Kandungan mineral ini tergoong rendah bila dibandingkan dengan penelitian Woycieszak et al. (2020) Ca: $0,57 \mathrm{~g} / \mathrm{kg}$; Na: 0,16 g/kg; Mg: 0,14 g/kg dan P: 0,58 g/kg, dan Cl: $0,88 \mathrm{~g} / \mathrm{kg}$.

Fungsi dari suplemen adalah untuk memenuhi zat-zat makanan yang tidak dapat dipenuhi dari hijauan. Suplemen berperan sebagai penyedia (NPN) dan karbohidrat mudah dicerna (RAC) meningkatkan perkembangbiakan mikroba rumen. Suplemen yang telah banyak digunakan untuk ternak ruminansia adalah urea molasses blok (UMB), tetapi karena keterbatasaan bahan baku molases di Sulawesi Utara, maka dicari alternatif lain berupa suplemen UGB. Pembuatan UGB sangat sederhana sehingga peternak dapat membuatkan sendiri, selain bahan bakunya (gula merah) yang mudah diperoleh.

Diharapkan dengan penelitian ini dapat digunakan untuk acuan dalam penanggulangan kekurangan mineral pada ternak yang mengalami defisiensi mineral.

\section{MATERI DAN METODE}

\section{Prosedur Penelitian, Bahan, dan Alat}

Peneltian ini dilaksanakan selama 3 bulan. Ternak yang digunakan terdiri dari 24 ekor kambing betina lokal, berumur \pm 1 tahun dengan berat badan $\pm 18 \mathrm{~kg}$.

Kandang yang digunakan adalah kandang individu dengan ukuran $2 \times 2 \times 1 \mathrm{~m}$, yang dilengkapi dengan tempat makan khusus untuk penempatan UGB.

Hijauan yang digunakan adalah jerami jagung, yang komposisinya dapat dilihat pada Tabel 1, sedangkan bahan yang digunakan untuk pembuatan UGB dapat dilihat pada Tabel 2.

Pakan tambahan UGB diberikan secara konstan sebanyak $300 \mathrm{~g} / \mathrm{ekor} /$ hari dan air minum diberikan secara ad libitum.

Ransum perlakuan yang diberikan diatur sebagai berikut

Ro = Jerami jagung ad libitum + o g UGB

$\mathrm{R} 1=$ Jerami jagung ad libitum $+300 \mathrm{~g}$ UGB

\section{Prosedur Pengukuran dan Analisis}

Parameter yang diamati adalah kadar mineral (Ca, Mg, P, K, Na, dan $\mathrm{Cl}$ ) dalam darah dan jumlah mikroba rumen.
Tabel 1. Kandungan Zat-zat Makanan dalam Jerami Jagung

\begin{tabular}{cc}
\hline Zat-zat makanan & Jerami jagung \\
\hline Bahan kering & $78,0 \%$ \\
Protein Kasar & $7,54 \%$ \\
Serat Kasar & $36,70 \%$ \\
Lemak & $1,74 \%$ \\
$\mathrm{Abu}$ & $14,00 \%$ \\
$\mathrm{Ca}$ & $0,03 \mathrm{~g} / \mathrm{kg}$ \\
$\mathrm{P}$ & $0,17 \mathrm{~g} / \mathrm{kg}$ \\
$\mathrm{Mg}$ & $0,03 \mathrm{~g} / \mathrm{kg}$ \\
$\mathrm{Na}$ & $0,08 \mathrm{~g} / \mathrm{kg}$ \\
$\mathrm{K}$ & $0,24 \mathrm{~g} / \mathrm{kg}$ \\
$\mathrm{Cl}$ & $0,10 \mathrm{~g} / \mathrm{kg}$ \\
$\mathrm{GE}$ & $4063,1(\mathrm{kal} / \mathrm{kg})$ \\
\hline
\end{tabular}

Laboratorium Fakultas Peternakan Unsrat (2019)

Tabel 2. Komposisi Penyusun UGB

\begin{tabular}{lc}
\hline \multicolumn{1}{c}{ Bahan baku } & Prosentase bahan (\%) \\
\hline Gula merah & 25 \\
Urea & 4 \\
Dedak padi & 20 \\
Bungkil kelapa & 9 \\
Garam & 2 \\
Mineral & 9 \\
Tepung ikan & 6 \\
Jagung & 25 \\
Jumlah & 100 \\
\hline
\end{tabular}

a. Prosedur pengukuran kandungan mineral dalam darah

Pengambilan sampel darah dilakukan melalui vena jugularis sebanyak 2 cc, kemudian darah dibekukan dan diambil serumnya. Selanjutnya disimpan dalam refrigerator sampai dilakukan analisis mineral ( $\mathrm{Ca}, \mathrm{Mg}, \mathrm{P}, \mathrm{K}, \mathrm{Na}$ dan $\mathrm{Cl}$ ). Bahan kimia yang digunakan untuk mengukur kandungan mineral dalam sampel darah dilakukan dengan reagen kit, dan pembacaan kadar mineral dilakukan dengan menggunakan spectrometer (AAS). Penanganan sampel darah dilakukan menurut petunjuk Fick et al. (1979).

b. Prosedur perhitungan populasi bakteri rumen Populasi bakteri rumen dicacah menggunakan metode pencacahan koloni. Bakteri yang dicacah hanya yang hidup. Prinsip perhitungan adalah cairan rumen diencerkan secara serial lalu dilakukan pembiakan bakteri dalam tabung Hungate selama 7 hari. Kultivasi bakteri dilakukan pada $\mathrm{pH}$ 7, dibuat suasana anaerob, dan pada suhu $39^{\circ} \mathrm{C}$. Media pembiakan yang digunakan adalah non selektif media untuk total bakteri (Ogimoto dan Imai, 1981).

\section{Analisis Data}

Data yang terkumpul diuji dengan $t$ test (Nuryadi et al., 2017). 


\section{HASIL DAN PEMBAHASAN}

\section{Pengaruh Pemberian Jerami Jagung dan UGB terhadap Kadar Mineral Dalam Darah}

Rataan kadar mineral dalam darah $(\mathrm{Ca}, \mathrm{Mg}, \mathrm{P}$, $\mathrm{Na}, \mathrm{K}$, dan $\mathrm{Cl}$ ) untuk perlakuan Ro dan R1 tersaji pada Tabel 3. Rataan R1 kandungan Ca serum darah 9,8 mg/dl, nilai ini berada dalam kisaran normal kandungan mineral darah menurut Churh (1979) yaitu 9-12 mg/dl. Dari hasil analisis statistik menunjukkan bahwa penambahan UGB dalam ransum memberikan pengaruh terhadap peningkatan kadar mineral dalam darah kambing. Hal ini sejalan dengan penelitian Delima (2008) menyatakan bahwa pemberian urea molasses mineral blok berpengaruh terhadap kadar mineral dalam serum sapi. Pemberian mineral blok ini dapat memperbaiki kondisi tubuh ternak yang mengalami gejala defisiensi mineral. Rataan R1 kandungan mineral $\mathrm{P}$ serum darah $7,3 \mathrm{mg} / \mathrm{dl}$ nilai ini masih masuk kisaran normal kadar mineral $\mathrm{P}$ menurut Church (2007) yaitu 4-8 mg/dl. pengaruh terhadap peningkatan jumlah mikroba dalam rumen. Hal ini sesuai dengan penelitian Kaunang (2004) yang menemukan bahwa pemberian nutrien yang mengandung mineral akan dapat meningkatkan populasi atau pertumbuhan bakteri rumen, dimana pada gilirannya dapat meningkatkan kecernaan bahan pakan dan pertambahan bobot badan ternak. Produktivitas ternak ruminansia secara biologis ditentukan oleh kinerja sistem rumen dalam mencerna bahan pakan, khususnya serat, yang diberikan kepada ternak. Kinerja fermentasi rumen dapat ditingkatkan melalui berbagai pendekatan, antara lain dengan pemberian suplemen (Haryanto et al, 1998). Penelitian Pudjihastuti et al. (2019) menunjukkan bahwa penambahan UGB dalam ransum sapi memberikan pengaruh terhadap peningkatan bobot karkas dan persentase karkas. Hal ini sejalan dengan pendapat Ella et al. (2004) yang menyatakan bahwa pemberian urea molasses blok (UMB) memberikan pertambahan bobot badan ternak $64 \mathrm{~g} /$ ekor/hari lebih tinggi dibandingkan dengan

Tabel 3. Rataan Kadar Mineral Dalam Darah

\begin{tabular}{|c|c|c|c|c|c|c|}
\hline \multirow{2}{*}{ Perlakuan } & \multicolumn{6}{|c|}{ Rataan Variabel Pengamatan } \\
\hline & $\mathrm{Ca}$ & $\mathrm{Mg}$ & $\mathrm{P}$ & $\mathrm{Na}$ & $\mathrm{K}$ & $\mathrm{Cl}$ \\
\hline Ro & $6,7 \mathrm{mg} / \mathrm{dL}$ & $10,4 . \mathrm{mg} / \mathrm{dL}$ & $2,3 \mathrm{mg} / \mathrm{dL}$ & $100 \mathrm{mmol} / \mathrm{L}$ & $4,0 \mathrm{mmol} / \mathrm{L}$ & $100 \mathrm{mmol} / \mathrm{L}$ \\
\hline $\mathrm{R} 1$ & $9,8 \mathrm{mg} / \mathrm{dL}$ & $13,9 \mathrm{mg} / \mathrm{dL}$ & $7,3 \mathrm{mg} / \mathrm{dL}$ & $145 \mathrm{mmol} / \mathrm{L}$ & $7,4 \mathrm{mmol} / \mathrm{L}$ & $121 \mathrm{mmol} / \mathrm{L}$ \\
\hline
\end{tabular}

Wibisono (2005) meneliti bahwa pemberian suplemen UGB dapat meningkatkan konsumsi bahan kering dan konsumsi protein serta pertambahan berat badan pada sapi. Hal ini dikarenakan adanya gula merah yang berfungsi sebagai perangsang untuk meningkatkan nafsu makan, sehingga secara naluri ternak akan menambah konsumsi bahan kering ransum. Penelitian Kaunang dan Sane (2008) menunjukkan bahwa penambahan UGB dalam ransum memberikan pengaruh nyata peningkatan bobot hidup kambing sebesar 19,5 kg. Juergerson (1974) menyatakan bahwa rasa manis dalam ransum dapat meningkatkan palatabilitas ransum. Menurut Van Soest (1991), rasa manis dapat meningkatkan selera makan. Rataan kadar mineral dalam penelitian ini ada yang berada di atas batas normal bila dibandingkan penelitian dari Olmedo Juarez et al. (2012) yaitu Ca:7,8 mg/dl: $\mathrm{Mg}:$ 2,95 mg/dl dan P: $3,06 \mathrm{mg} / \mathrm{dl}$ dan sebagian ada yang berada dibatas bawah normal (Na:322 mmol/L, K:17.31mol/dl dan $\mathrm{Cl}: 200 \mathrm{mmol} / \mathrm{dl})$

\section{Pengaruh Pemberian Jerami Jagung dan UGB terhadap Jumlah Bakteri Dalam Rumen}

Rataan jumlah bakteri untuk perlakuan Ro dan R1 tersaji pada Tabel 4. Dari hasil analisis menunjukkan bahwa penambahan UGB dalam ransum memberikan tanpa UMB 53 g/ekor/hari karena pemberian UMB akan menciptakan kadar lingkungan pertumbuhan mikroba yang optimal untuk rumen dan tersedia pula protein yang dapat diserap tubuh sehingga memberi respons pertambahan bobot badan.

Tabel 4. Rataan Jumlah Bakteri dalam Rumen

\begin{tabular}{cc}
\hline \multirow{2}{*}{ Perlakuan } & Rataan Variabel Pengamatan \\
\cline { 2 - 2 } & Bakteri \\
\hline Ro & $15,69 \times 10^{8} / \mathrm{mL}$ \\
R1 & $25,08 \times 10^{8} / \mathrm{mL}$ \\
\hline
\end{tabular}

Proses pencernaan pada ruminansia lebih banyak ditentukan oleh pencernaan fermentatif di dalam rumen. Hal ini dikarenakan selain kapasitas rumen paling tinggi (70\%) dari kapasitas saluran pencernaan secara keseluruhan, juga disebabkan oleh ekosistem rumen dan aktivitas mikroba rumen itu sendiri yang sangat menentukan kecernaan fermentatif. Mineral makro seperti $\mathrm{Ca}, \mathrm{Mg}, \mathrm{P}, \mathrm{Na}, \mathrm{K}$, dan $\mathrm{Cl}$ merupakan senyawa yang dibutuhkan mikroba untuk proses metabolisme rumen (Hungate, 1988; Orskov dan Ryle, 1990). Zat-zat mineral makro diperlukan dalam jumlah besar yang terdiri dari $\mathrm{Ca}, \mathrm{Mg}, \mathrm{Na}$, dan $\mathrm{K}$ sebagai kation utama serta $\mathrm{P}$ dan $\mathrm{Cl}$ sebagai anion utama. Zat-zat tersebut tidak dapat disimpan dalam tubuh sehingga diperlukan penambahan secara teratur 
dalam makanannya (Anggorodi, 1979). Arora (1995) berpendapat bahwa mineral bagi ternak ruminansia, selain untuk memenuhi kebutuhannya sendiri juga digunakan untuk mendukung dan memasok kebutuhan mikroba rumen. Apabila terjadi defisiensi salah satu mineral maka aktivitas fermentasi mikroba tidak berlangsung optimum sehingga akan berdampak pada menurunnya produktivitas ternak.

\section{SIMPULAN}

Dari hasil penelitian ini dapat disimpulkan bahwa pemberian jerami jagung dan suplemen UGB dapat meningkatkan kadar mineral (Ca, Mg, P, Na, K, dan Cl) dalam darah dan jumlah bakteri dalam rumen kambing.

\section{DAFTAR PUSTAKA}

Aurora, S. P. 1995. Pencernaan mikroba pada ruminansia.UGM Press.Yogyakarta.

Anggorodi. 1979. Ilmu Makanan ternak Umum. Penerbit PT Gramedia. Jakarta.

Church, D. C. 1979. Digestive Physiology and Nutrition of Ruminant.Vol2nd Eds. Oxford Press. Porland, Oregon.

Delima, M. 2008. Pengaruh pemberian UMB terhadap kadar mineral serum sapi yang memperlihatkan gejala defisiensi mineral. Agripet. Vol.8 No.1.

Ella, A. D. Pasambe, dan A. B. Lompengeng. 2004. Pengaruh perbaikan pakan melalui suplementasi UMB terhadap bobot badan kambing lepas sapih. Semnas Teknologi Peternakan dan Veteriner.

Fick, K., R. L Mc Dowell., F. H Milles, N. S. Wilkingon, J. D Funk and J. H. Conrad. 1979. Method of mineral analisys for plant and animal tissues. 2 nd.ED. University of Florida. Gainsvile Florida.

Haryanto, B., A. Thalib, dan Isbandi. 1998. Pemanfaatan Probiotik dalam Upaya Peningkatan Efisiensi Fermentasi Pakan di Dalam Rumen. Pros. Sem. Nas. Peternakan dan Veteriner. Puslitbangnak. Bogor.
Hungate, R.E. 1988. The Rumen and Its Microbs. Applied Science Academic. Press, New York.

Juergerson 1974. Approved Practices on Beet Cattle Production. The Ontersate Denville. Illinois.

Kaunang, C. L. 2004. Respons Ruminan Terhadap Pemberian Hijauan Pakan yang dipupuk Air Belerang. Disertasi. IPB Bogor.

Kaunang, C. L. dan Sane. S. 2018. Profil karkas kambing yang diberi suplemen UGB. Jurnal LPPM Bidang Sains dan Teknologi. Unsrat. Vol. 5. No.1.

Nuryadi, T. D Astuti, E. S. Utami. dan M. Budiman. 2017. Dasar dasar Statistik Penelitian, Universitas Mercubuana.

Ogimoto, K and S. Ismai, 1981. Atlas of Rumen microbiology. Japan Sci. Press.Tokyo.

Olmedo-Juarez, A., R. Rojo., A. Z. M. Salem., J. F. Vazquez-Armijo., S. Rebollar-Rebollar; B. Albarran, and J. Lugo. 2012. Concentration of some elements in blood serum of nonlactating goats in a subtropical, region of southwest of Mexico state. Tropical and Subtropical Agroecosystems,15:71-75.

Orskov, E. R and M. Ryle. 1990. Energy Nutrition in Ruminant. Eisevier Applied Science. London.

Pudjihastuti, E., J. R. Bujung, dan C. L. Kaunang. 2019. Profil karkas dan status hematologis darah dari sapi yang diberi UGB. Jurnal MIPA Unsrat online Vol 8(3):168-171.

Van Soest, P. J. 1991. Nutritional Ecology of Ruminant. $\mathrm{O}$ and B Book. The Corvallis

Wibisono, A. K. M. 2005. Produktivitas Sapi Lokal yang diberi Suplemen Gula Merah Blok. Skripsi FAPET UNSRAT.

Wojcieszak.D, J. Przybyt, I. Ratajczak, P. Golinski, D. Janczak., A. Waskiewicz, K. Szentner, and M. Wozniak. 2020. Chemical composition of maize stover fraction versus methane yiedl and energy value in fermentation process.J. Energy 198. 